\title{
The Effect of Toll Gate Type on the Queue of Vehicles in Connecting Roads: A case study of Bawen - Yogyakarta Toll Road
}

\author{
Herna Puji Astutik*, Dewanti \\ Department of Civil and Environmental Engineering Universitas Gadjah Mada, Yogyakarta, INDONESIA \\ Jalan Grafika No 2 Yogyakarta \\ *Corresponding: herna.pujiastutik@yahoo.com
}

SUBMITTED 07 November 2018 REVISED 08 November 2018 ACCEPTED 09 November 2018

\begin{abstract}
Due to the increased population, accessibility from one place to another, and effort to support economic growth, the Indonesian Central Government plans to build 71 kilometers of Yogyakarta-Bawen Toll Road. It is, however, important to state that the technical requirements of a connecting road are an integral part of the toll road construction. Therefore, this research was conducted to determine the sufficient length for the connecting road between the toll gate and existing one to reduce the investment of Toll Road Business Entity and ensure a more extended return period of concession. The data used include the vehicle speed and daily traffic on the road while the maximum length value of vehicle queue occurring in the peak hour period and interval for each type of toll gate was calculated in the modeling simulation. The results showed the satellite gate with 4 lines has 159 meters, tandem with 2 lines has 434 meters, and extending with 3 lines has 513 meters. Since all the gates have less than 2 kilometers of queue length, the stretch of the connecting road in each toll of the plan needs to be analyzed to ensure effective development.
\end{abstract}

KEYWORDS Toll Gate; Queue Length; Connecting Road; PTV Vissim 8

(c) The Author(s) 2020. This article is distributed under a Creative Commons Attribution-ShareAlike 4.0 International license.

\section{INTRODUCTION}

The increasing population, need for accessibility from one place to another, and effort to encourage economic growth on Java Island has caused the Central Government to plan a Yogyakarta-Bawen Toll Road with a length of 71 $\mathrm{Km}$. This is essential to advance national connectivity as stated in the 2015-2019 Indonesia's National Medium Term Development Plan (Outline Business Case Jalan Tol Bawen Yogyakarta, 2018).

The planned route is expected to use the lane in the Selokan Mataram area of Sleman Regency. This is necessary because connecting roads are integrated components of the toll ones and are part of the obligations of the Toll Road Companies which construct them in a similar structure based on existing conditions. However, the length of the connecting road is set by the government to be at least $2 \mathrm{~km}$ according to (Direktorat Jendral Bina Marga, 2009) and this requires a significant investment and longer return time for the concession. Besides, the roads are not included in the range of space paid by users as tolls.

Moreover, Yogyakarta is massively developing, and this caused a decrease in the green areas and the need for large domains to build a connecting road between the toll gate and the existing roads. It is, however, important to put more effort to keep existing green areas from diminishing while supporting continuous national development.

Therefore, there is need for a model to determine the value of delays and queues in each type of toll 
gate to illustrate the effective length of connecting roads required by each type of toll gate in Bawen-Yogyakarta Toll Road to ensure efficient use of green land and reduction in the construction investment for Toll Road Companies.

\section{TOLL ROAD PROPERTIES FOR MODELLING}

Toll roads are very important to the transportation system in Indonesia because they greatly influence the smooth movement of people and goods (Abdurrofi, 2017) . Their performance is, however, determined through the use of model simulation, field observations, and also statically tested through the process of the calibration and validation in the VISSIM model (Yulianto, et al., 2017).

According to Satriotomo (2011) in the Effectiveness of Semarang City Toll Road Services to Meet User Needs, argued the conditions, average speed, and safety provided by toll roads need to be higher than the non-toll ones.

The VISSIM model developed in this research could be a useful tool for relevant authorities and transportation agencies in designing or retrofitting toll facilities. It is also expected to have wider applicability in the analysis of different demands, origin-destination distributions, and other toll plazas to test operational performance. The major benefit of this study is to ensure toll plaza efficiency as well as the most effective use of existing infrastructures (McKinnon, et al., 2014).

\subsection{Toll Gate}

In the 1997 Indonesian Road Capacity Manual, a freeway is defined as a road constructed to ensure continuous traffic with full entrance control, both for separated and unseparated roads. This definition is used in the country for 'toll road' in the present time. Similarly, according to the
Directorate of Public Works, the Ministry of Public Works and Housing (2009) requires the Geometric Standards for Highways to meet the aspects of safety, security, comfort, and smooth traffic as follows:

1. Considering the traffic aspects that are useful as toll roads, level of road development, design standards, maintenance, class, and function of roads, and the entrance/exit booth, and interchanges;

2. Fulfilling the standard geometry requirements specifically designed for freeways with toll collection systems;

3. Considering technical, economic, financial, and environmental factors;

4. Fulfilling higher class, specifications, and control from the existing public roads;

5. Planning to be able to serve long-distance traffic with high mobility;

6. Using techniques to ensure alignment exists between the horizontal and vertical; and

7. Considering the availability of adequate side channels.

The Geometric Standards for Highways concerning Toll Roads also regulate the dimensions of toll equipment size with the gate expected to be $2,90 \mathrm{~m}$ wide while the island should be 2,10 m wide. To be able to serve special situations, such as transportation with special vehicles that have extra width, the outer (left) lane should have a minimum width of $3,50 \mathrm{~m}$.

\subsection{Types of Toll Gate}

1. The toll gate is a transaction service place for road users consisting of several booths and other facilities. These gates are modified by operators to meet certain demands and this has led to several types but, in Indonesia, only satellite and tandem are applied as shown in Figure 1. 

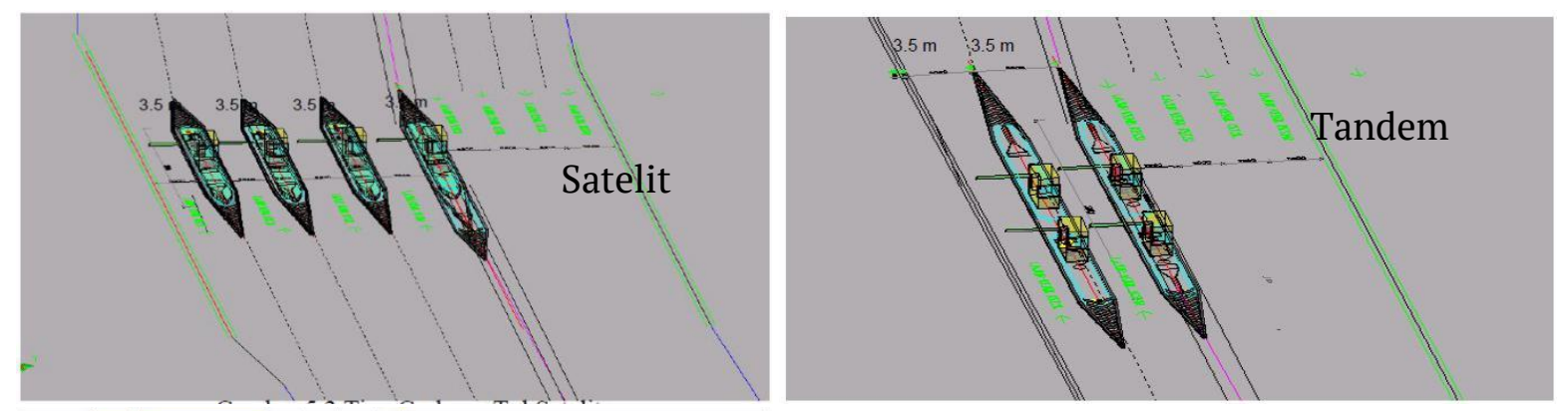

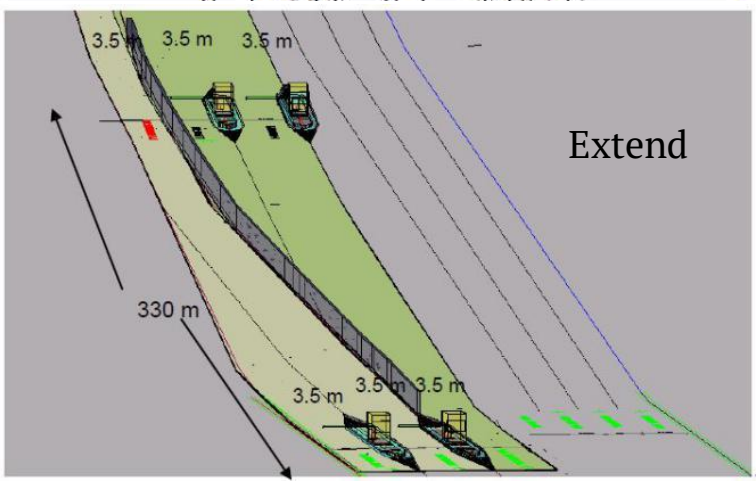

Figure 1. Layout of Different Types of Toll Gate

The applications of each type are as follows:

a. The tandem type was adopted in 1981 at Golden Gate Bridge and it involves the use of two manual toll gates placed on the same line on the toll lane, allowing simultaneous processing of two vehicles. The aim is to reduce waiting times between vehicles on the lane, thereby, reducing the processing rate per vehicle (Schaufler, A. E, 1997). This type is often used in Indonesia when in an emergency, for example, during the Idul Fitri Mudik (exodus) season. It is also applied when there is limited land for the toll road which makes expansion or addition of new lanes impossible. Other examples are in the Ir. Wiyoto-Wiyono and, situationally, in the Merak toll road.

b. Satellite type is a toll gate with one line/lane as well as one booth to service toll payments, both manually and with the GTO system (Automatic Toll Gate). This is very common in Indonesia, such as in the Trans Java Cikampek and Cipali toll roads.

Extended type involves tollgates covering several locations at a certain distance due to limited land as observed in Semanggi I and II Toll Roads in Jakarta. Since there is no space for expansion as in satellite type, a simulation is used to ensure the available booth meets all the required toll transactions

\subsection{Toll Gate Service Time}

According to the Geometric Standards for Highways concerning Toll Roads (Direktorat Jendral Bina Marga, 2009), the toll collection system and equipment capabilities, as well as the skills and readiness of collection officers and road users greatly, influence the service time. The set of service time is as follows:

a) Open toll collection system: Entry/exit booth: 6 seconds

b) Closed toll collection system: Entry booth: 4 seconds, Exit booth: 10 seconds

According to Woo, Hugh and Hoel, Lester A in Toll Plaza Capacity and Level of Service, an imaginary reference line was developed to determine the service time for a toll booth. It is the point located, $55 \mathrm{ft}$ from where the toll attendant stands for a general toll booth and $50 \mathrm{ft}$ for an exact-change booth, where the rear of a 
vehicle passes when another one stops to pay the toll. The service times ranged between 12.87 and $14.88 \mathrm{sec}$ for trucks and 5.11 to $5.47 \mathrm{sec}$ for automobiles. Furthermore, automobile service times at exact-change booths are shorter or exhibit little or no difference from those at general booths. Moreover, the service time was defined by these authors to be the elapsed time for a vehicle to stop, pay a toll, and move for the next vehicle in the queue.

\subsection{Connecting Road}

Connecting road connects the toll road with the existing ones with the management responsibility attached to a Toll Road Company. This road is usually constructed in a similar pattern with the toll roads based on the engineering plan in accordance with Article 27 of the Government Regulation of the Republic of Indonesia Number 15 of 2005 concerning Toll Roads. Moreover, the technical planning of toll road involves the collection of several documents describing the project such as the detailed technical drawings, general requirements, and job specifications regarding the initial design. Furthermore, the Geometric Standards for Highways concerning Toll Roads (2009) which regulates the connecting roads to ensure smooth flow of traffic states that the minimum length should be $2 \mathrm{~km}$ with technical analysis and due consideration for the balance of capacity between the toll gates and intersections. This means a large area of land is required for its construction and this can be minimized through the use of appropriate analysis.

\section{RESEARCH METHOD}

\subsection{Research Location and Gate Type Plan}

This research reviewed several pieces of literature and traffic survey results to collect the data related to Bawen -Yogya Toll Road which were further analyzed to plan the appropriate gate scheme.

It was conducted according to the layout plan of the Committee for Acceleration of Priority
Infrastructure Delivery 2018 such that when the allocation was superimposed on the map, the initial gate is located in Sleman Regency, Yogyakarta as shown in Figure 2.

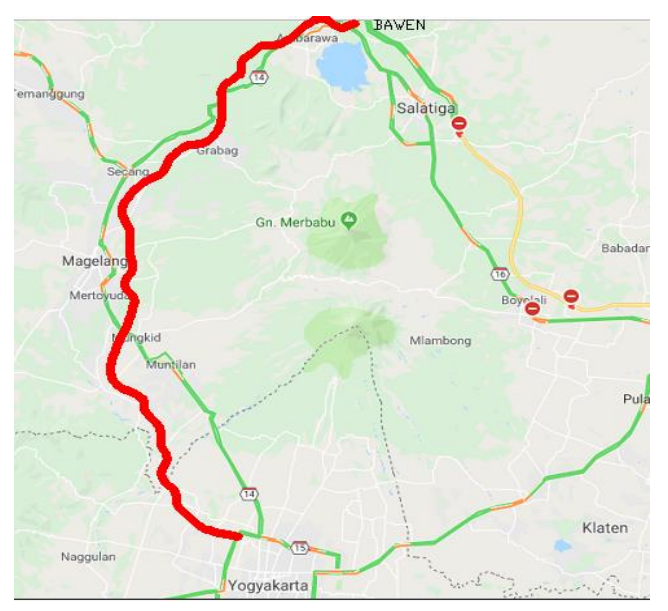

Figure 2. Layout Option for the Selection of YogyakartaBawen Toll Road (Source: Komite, 2018)

Three types of gate were used and they include

1. Satellite with several lanes according to the needs of the booth.

2. Tandem with several lanes and a divider to separate the booths.

3. Extended with several lanes a divider separating the number of booths at a certain distance.

The steps involved in the analysis are as follows:

1. Formulation of the Problem At this stage, the problem was classified and examined as a basis of the study.

2. Literature Study

Several sources were collected from previous research for references.

3. Research Methods

An overview of the processes involved in the conduct of the research was presented to ensure readers understand the flow.

4. Data Collection

Data was collected to support the research.

5. Three Types of Tollgate Modeling

The types of toll gate highlighted were simulated using the VISSIM software to obtain queue and delay results at each gate. 
6. Data Processing and Software Calibration Process

Data collected were processed using PTV VISSIM software and calibrated to adjust the existing conditions to the processed model.

7. Results

This was obtained after modeling and analysis.

8. Conclusion

Providing conclusions based on the results

9. Suggestion

Providing suggestions based on the results of the research conducted and scenarios applied.

\subsection{Microscopic Simulation}

This research utilized a microscopic simulation to imitate the queue and delay performance in Toll Gate of Bawen - Yogyakarta Toll Road by using Vissim software. Each vehicle in the traffic network was continuously modeled throughout the simulation period based on some behavior models such as car-following and lane changing. Some of the data used according to (Dowling R, et al., 2004) include:

1. Geometry design such as lengths, lanes, and curvature.

2. Controls such as signal timing and signs.

3. Existing demands such as turning volumes and origin-destination.

4. (O-D) table.

5. Calibration data such as capacities, travel times, and queues.

A queue is a common phenomenon in daily life as observed in obtaining tickets for train, movie, cinema, toll gate or queuing in the bank, supermarket, and other places and situations. However, some of the factors identified by Andriyanto, A \& Munawar, A, (2014) to be causing queues and delays at toll gates include

1. Traffic

2. Service time

3. Type of toll gate services (manual/automatic)

4. Vehicle types and specifications

5. Time of vehicle movement after service
Moreover, Negoro (2018) also added speed management as one of the factors affecting the queue.

According to Gomes, G, et al. (2004), model construction procedure consists of (1) identification of important geometric features, (2) collection and processing of traffic data, (3) analysis of the main-line data to identify recurring bottlenecks, (4) VISSIM coding, and (5) calibration based on observations from Step 3 and this requires a qualitative set of goals which are relatively modified to satisfy Vissim's driver behavior parameters. Moreover, according to (Aryandi, R. D \& Munawar, 2014), Vissim is a software developed by PTV (Planung Transport Verkehr) AG in Karlsruhe, Germany to simulate the microscopic multi-modal traffic, public transportation, and pedestrians. It is the most sophisticated tool available for the simulation of the traffic of cars, freight transport, buses, heavy rail, tram, LRT, motorcycles, bicycles, and pedestrians.

Yulianto, et al. (2017) reported there is no significant difference with the simulation model of the software and the actual traffic conditions. Moreover, it also has the ability to determine the value of road capacity and simulate a road network in mixed traffic conditions with a microsimulation approach Irawan, M. Z \& Putri, N. H. (2015) showed the software contains speed management parameters and can be used as an alternative to resolving queuing problems at the Exit Booth Toll Gate using future speed management strategies. For example, $\mathrm{Zhu}, \mathrm{Z}$, et al. (2016) adopted VISSIM to investigate the urban expressway off-ramp control problems while Yulianto, et al. (2017) discussed the use of the calibration process to model traffic conditions. It is, however, important to state that the driving behavior parameters in Vissim have different sensitivity and needed accuracy in the value modifier. 


\subsection{The Wiedemann 99 Characteristics of Driver Behavior in Vissim}

It is a model used in the Vissim program where the highway and urban traffic modeling requires the application of several parameters such as:

1. CCO (Standstill Distance) is the desired safe distance between two vehicles without any variation.

2. CC1 (Headway Time) is the time (in seconds) which the driver maintains the speed to keep the distance. A higher value requires the driver to be more careful. Moreover, the safe distance in this parameter can be stated as $\mathrm{dx}$ safe $=\mathrm{CC} 0+\mathrm{CC} 1 \times \mathrm{v}$, where $\mathrm{v}$ is the speed.

3. A safe distance is a minimum distance the driver wants to maintain while following a lead vehicle.

4. CC2 (Following Variation) is the safest distance desired and allowed before the driver approaches the lead vehicle.

5. CC3 (Threshold to Follow) is when the driver starts to decelerate having realized the lead vehicle is moving slower. It explains the seconds required to reach a safe distance for deceleration.

6. CC4 and CC5 (Following Threshold) are parameters to set the speed difference during the following conditions ((-) value on CC4 for negative speed and $(+)$ value for positive speed).

7. CC6 (Speed Dependency of Oscillation) is the effect of distance on moving speed during the following process. A greater CC value shows the vehicle is aiming for an increasingly fastmoving speed with increasing distance.

8. CC7 (Oscillation Acceleration) is a parameter that explains simple acceleration as long as the vehicle is moving.

9. CC8 (Standstill Acceleration) is the desired acceleration when the vehicle is standstill and limited by a maximum acceleration in the curve

10. CC9 (Acceleration with $80 \mathrm{~km} / \mathrm{h}$ ) is the desired acceleration at a speed of $80 \mathrm{~km} / \mathrm{h}$ and limited by a maximum acceleration in the curve.

\subsection{Calibration and Validation in Vissim}

The use of the Vissim software requires calibration and validation to ensure the modeling was conducted based on observation. The process can be calibrated through the use of a trial and error method on the driving behavior menu. This is very important to ensure the conditions of the modeling approach the actual ones. Moreover, the aim was to determine the best value of a set of parameters in each software (Ronaldo, A., 2012). According to Irawan and Putri (2015), calibration in VISSIM is a process of forming the appropriate parameter values to ensure the model replicates traffic conditions as similar as possible. It is usually conducted based on driver behavior in the observed area. This research, however, used the trial and error according to previous studies that have used the same software.

Validation in VISSIM is a process of verifying truth from calibration by comparing the observed and simulated results involving the traffic volume and queue length. The method used was the basic Chi-square equation in the form of a statistical formula of Geoffrey E. Havers (GEH) which combined the differences between relative and absolute values and also has specific provisions for the error value generated as shown in the following formula:

$G E H=\sqrt{\frac{\left(q_{\text {simulated }}-q_{\text {observed }}\right)^{2}}{0,5 x\left(q_{\text {simulated }}+q_{\text {observed }}\right)}}$

Where $q_{\text {simulated }}$ is the data on simulated traffic flow volume (vehicle/hour) and $q_{\text {observed }}$ is the data on observed traffic flow volume (vehicle/hour).

\section{RESULTS AND DISCUSSIONS}

After the use of the ultimate daily traffic plan and average vehicle speed survey data for modeling by the application of the Vissim software, a queue length data variation was obtained due to the movement of traffic on each type of toll gate as shown in Table 1 
The results presented in Table 1 show maximum queue length for the modeled three types of gates using the PTV VISSIM software and the value for the Tandem was found to be 432,9 meters with two lanes as shown in Figure 3. This is considered to be a much smaller number since the ultimate traffic volume is predicted to be 433 meters thereby reducing the length of the $2 \mathrm{~km}$ connecting road stipulated by the rules.

The maximum value for the Extended was observed to be 515,95 meters with three lanes as shown in Figure 3. This is considered to be a much smaller number since the ultimate traffic volume is predicted to be 516 meters thereby reducing the length of the $2 \mathrm{~km}$ connecting road stipulated by the rules.

The value obtained for the satellite gate was relatively smaller compared to both tandem and extended types due to its four lanes and four booths. This means each of the lanes can directly service vehicles for toll payment and reduce the tendency of changing lanes thereby leading to the minimization of queue compared to other gates. The tandem gate has a higher queue length value compared to the Satellite because it only has two lanes with four booths which means each lane is being serviced with two booths at once and this is one of the factors causing long queue considering the road capacity is only half of what is observed with the Satellite Gate.

The extended gate has the highest queue length value compared to the others, although it has more lanes than the tandem. It also encourages more lane changing attributes than other gate types such that the drivers are allowed to change the lane to transact at the next gate, and since this delay other road users, it has the ability to cause longer queues when compared with other types.

Table 1. Characteristics of Each Toll Gate Type

\begin{tabular}{|c|c|c|c|c|}
\hline No. & Parameter & Satellite & Tandem & Extended \\
\hline 1 & $\begin{array}{l}\text { Number of } \\
\text { lanes }\end{array}$ & 4 & 2 & 3 \\
\hline 2 & Lane width & $14.0 \mathrm{~m}$ & $7.0 \mathrm{~m}$ & $10.5 \mathrm{~m}$ \\
\hline 3 & Queue length & $153.00 \mathrm{~m}$ & $433.60 \mathrm{~m}$ & $513.94 \mathrm{~m}$ \\
\hline 4 & $\begin{array}{l}\text { Existing } \\
\text { Practices }\end{array}$ & $\begin{array}{l}\text { Widely used in several toll } \\
\text { roads because of its easy } \\
\text { application, both } \\
\text { automatically and } \\
\text { manually }\end{array}$ & $\begin{array}{l}\text { Used only in } \\
\text { emergency/situational } \\
\text { conditions through the } \\
\text { application of the manual } \\
\text { system because the } \\
\text { automatic system is still } \\
\text { under development. }\end{array}$ & $\begin{array}{l}\text { Applied due to limited land } \\
\text { conditions for a road } \\
\text { extension. } \\
\text {. }\end{array}$ \\
\hline 5 & Advantages & $\begin{array}{l}\text { Requires more lanes } \\
\text { Automatic system available } \\
\text { Fewer vehicle movement }\end{array}$ & $\begin{array}{l}\text { Each lane can serve two toll } \\
\text { payment transactions } \\
\text { Less road width and lower } \\
\text { land acquisition rate. }\end{array}$ & $\begin{array}{l}\text { Less lane width as suited to } \\
\text { the needs of the booth }\end{array}$ \\
\hline 6 & Disadvantages & More lane width & $\begin{array}{l}\text { The transaction system is } \\
\text { not automatic yet. } \\
\text { The connecting roads use a } \\
\text { lot of the alignment length } \\
\text { provided compared to the } \\
\text { satellite type. }\end{array}$ & $\begin{array}{l}\text { A higher number of vehicle } \\
\text { movement in each lane } \\
\text { The connecting roads use a } \\
\text { lot of the alignment length } \\
\text { provided compared to the } \\
\text { satellite type. }\end{array}$ \\
\hline
\end{tabular}



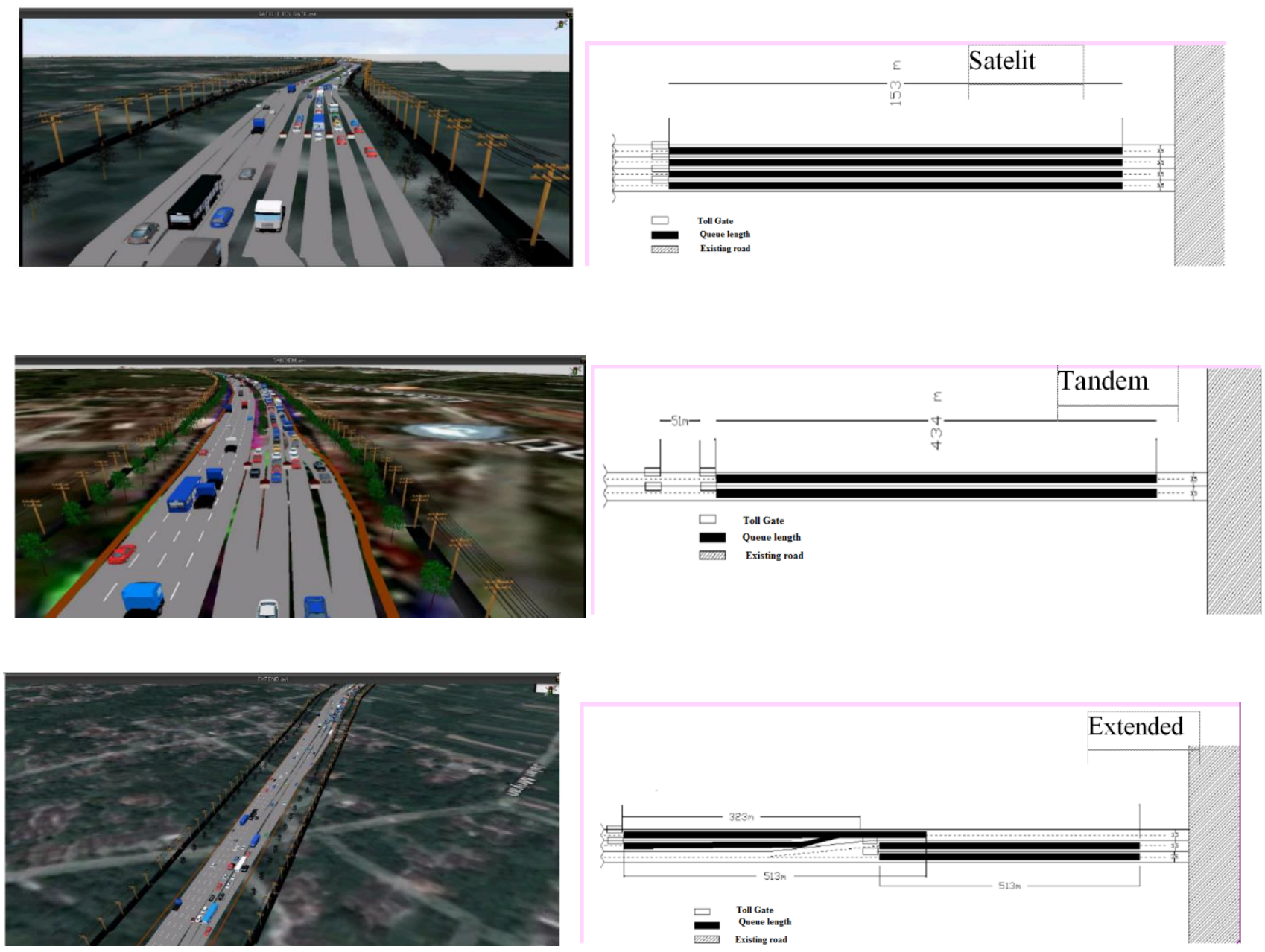

Figure 3. Demonstration and Illustration of the queue length value in the Vissim

\subsection{The Consequences of Each Agency}

The consequences of these gates vary depending on the following institutions.

\subsubsection{Government}

This is the highest institution in toll road development and maintenance. It is responsible for the acquisition of land based on predetermined alignment and required area of the design as approved by the Toll Road Operator. The followings are the consequences for the government:

\section{a. Satellite Type}

The government needs to acquire more land because this gate needs a wider area than the others. b. Tandem Type

The government obtains more benefits because the required road width is lesser than the satellite type and it is also possible for the Toll Road Company to modify the conditions of the length of the alignment provided as the connecting road.

c. Extended Type

The benefits obtained by the Government is the same as the tandem type.

\subsubsection{Toll Road Company}

Toll Road Company is a concession holder decided by the Government to finance the development of the toll road, appoint the contractors and consultants to supervise the implementation of work through the auction process, and operate the toll road after 
completion. The consequences of each type of gates on this institution are as follow:

a. Satellite Type: In this type, the Toll Road Company benefits greatly from having more land to construct connecting roads, ensure easier selection of the type of booths to be used, either automatic or manual, and also make modification simpler when the traffic conditions are beyond predictions.

b. Tandem Type: This involves the use of only manual systems due to the unavailability of appropriate technology in Indonesia. Moreover, due to the long queue generated, the length of the alignment provided by the Government is reduced and this also causes a reduction in the toll road length.

c. Extended type: In this type, the queue value and land needed is greater to reduce the length of the toll road to be used as connecting roads.

\subsubsection{Community}

The community expects an access road to reduce travel time compared to the use of the existing one mostly due to the amount of money that has been paid. However, for the community, the use of each type of gate also has some consequences:

\section{a. Satellite Type}

This type provides convenience for the community to select a preferred booth for payment in a lane since there are no variations. Moreover, the value of the queue is lower than in other types and this makes the service time shorter, thereby, providing more comfort for the community.

b. Tandem type

This also provides choices for transactions in a single lane but characterized by a longer queue than the satellite gate, therefore, there is less comfort using this type.

c. Extended Gate Type

This type provides a channel lane for people to make a payment due to limited availability of land and this causes lane-changing, and consequently, a long queue, therefore, there is also a lesser comfort using this type of gate.

\subsubsection{Local Government of Yogyakarta}

The Local Government of Yogyakarta, especially for the Sleman Regency, is mainly affected by the land to be acquired. According to Law Number 41 of 2009 concerning the Protection of Sustainable Food Agriculture and Special Region of Yogyakarta Provincial Regulation Number 10 of 2011 concerning the Protection of Sustainable Food Agriculture, lands are to be sustainably protected to ensure the availability of sustainable food and agriculture, realize self-reliance, resilience and food sovereignty, protect the ownership of food crops owned by farmers, increase prosperity and welfare farmers and the community, increase protection and empowerment of farmers, enhance employment opportunities for a decent life, maintain ecological balance, and realize agricultural revitalization. Moreover, the Sleman Regency has announced the use of 15.000 ha of land for sustainable agriculture. However, with the Central Government's plan to build toll roads, these programs may not be achievable due to the limited availability of land in the region.

\section{CONCLUSIONS}

Microscopic simulation using Vissim software was conducted to simulate the queue and delay performance in Toll Gate of Bawen - Yogyakarta Toll Road. Three types of gate were modeled and they include satellite, tandem, and extended. The results showed an effective connecting road length was less than the $2 \mathrm{~km}$ required by the Geometric Standards for Highways and this means it is an ineffective design. Furthermore, the use of satellite gate-type requires more land compared to others.

Therefore, the stakeholders are advised to review the design of the connecting road to maximize land use and ensure toll road effectiveness. Moreover, tandem or extended gate types are 
recommended to minimize the required land during the construction phase using recent technologies.

\section{DISCLAIMER}

The authors declare no conflict of interest.

\section{REFERENCES}

Abdurrofi, M, 2017. Evaluasi Kinerja Antrin dan Pengelolaan Operasi Gerbang Tol Kanci. Universitas Gadjah Mada.

Abdurrofi, M., 2017. Evaluasi Kinerja Antrin dan Pengelolaan Operasi Gerbang Tol Kanci, s.l.: Universitas Gadjah Mada.

Andriyanto, A \& Munawar, A, 2014. Simulasi Antrian Pintu Tol dengan Menggunakan Pemrograman Komputer (Studi Kasus Pintu Tol Cililitan), Yogyakarta: Universitas Gadjah Mada.

Aryandi, R. D \& Munawar, A., 2014. Penggunaan Software Vissim untuk Analisis Simpang Bersinyal (Studi Kasus Simpang Mirota Kampus Terban Yogyakarta). Jember, Proceeding The International University Transportation Studies Forum.

Asian Development Bank, 2012. Funds. [Online] Available

http://www.adb.org/site/funds/funds

[Accessed 28 June 2013].

Bapenas, 2018. Outline Business Case Jalan Tol Bawen, Jakarta: Badan Perencana Pembangunan Nasional .

Chow, V. T., Maidment, D. R. \& Mays, 1988. Applied Hydrology. New York: Mc. Graw-Hill Book Company.

Direktorat Jendral Bina Marga, 2009. Standar Geometri Jalan Bebas Hambatan Untuk Jalan Tol, Jakarta: Departemen Pekerjaan Umum Direktorat Jenderal Bina Marga.
Dowling R, Skabardonis A \& Alexiadis V, 2004. (FHWA)Traffic Analysis Toolbox Volume III: Guidelines for Applying Traffic Microsimulation Modelling Software. Washington: Federal Highway Administration.

Gomes, G, May, A \& Horowitz, R, 2004. Calibration of VISSIM for a Congested Freeway. Transportation. March, p. 46.

Irawan, M. Z \& Putri, N. H, 2015. Kalibrasi Vissim Untuk Mikrosimulasi Arus Lalu Lintas Tercampur Pada Simpang Bersinyal (Studi Kasus: Simpang Tugu, Yogyakarta). Jurnal Penelitian Transportasi Multimoda, Volume 13(3), p. 97-106.

Matsumoto, H., Veldhuis, J., de Wit, J. \& Burgh, G., 2008. Network Performance, Hub Connectivity Potential, and Competitive Position of Primary Airports in Asia/Pacific Region. Athens, Air Transport Research Society Conference.

McKinnon, I. A., Knodler, M \& Christofa, E., 2014. Operational Analyses of Varied Toll Plaza Configurations. The New England Chronicle, 54(3), pp. 11-16.

Negoro, Y. A., 2018. Analisa Pengaruh Manajemen Kecepatan Terhadap Antrian Kendaraan Pada Exit Gerbang Tol Periode Lebaran, Yogyakarta: Universitas Gajah Mada.

Pamungkas, T. Y. D., 2015. The Issues of Track Maintenance Management In Indonesia (based on Study of the British Railways), Yogyakarta: Master Thesis Report. Department of Civil and Environmental Engineering. Universitas Gadjah Mada.

Ronaldo, A., 2012. Comparison Of The MicroSimulation AISUM \& Highway Traffic Performance Analysis. Journal Of Civil Engineering Forum, September, Volume 21, p. 131-1310. 
Roy, V., Majumder, S. \& Sanyal, D., 2010. Analysis of the Turbulent Fluid Flow in an Axi-symmetric Sudden Expansion. International Journal of Engineering Science and Technology, 2(6), pp. 1569-1574.

Satriotomo, D, 2011. Efektivitas Layanan Jalan Tol Kota Semarang Dalam Memenuhi Kebutuhan Pengguna, Universits Diponegoro: s.n.

Schaufler, A. E, 1997. Toll Plaza Design, Washington, DC: National Academy Press.

Transportation Research Board, 2010. ACRP Report 37 - Guidebook for Planning and
Implementing Automated People Mover Systems at Airports, Washington, D.C: FAA.

Yulianto, Aditya, R. \& Munawar, A, 2017. Penentuan Kapasitas Jalan Bebas Hambatan Dengan Aplikasi Perangkat Lunak Vissim. Volume 17(2), pp. 123-132.

Zhu, Z., Shaohui, C., Yanquan, Y., Auixiu, H., \& Xinyi, Z., 2016. VISSIM Simulation-Based Expressway Exit Control Modes Research. Procedia Engineering, Volume 137, p. 738-746. 
[This page is intentionally left blank] 